\title{
Potential of Metarhizium anisopliae (Metsch.) Sorokin (Ascomycetes, hypocreales) in the control of Bonagota salubricola (Meyrick) (Lepidoptera, Tortricidae) and its compatibility with chemical insecticides
}

\author{
Anhalt, FA. ${ }^{\mathrm{a}}$, Azevedo, JL. ${ }^{\mathrm{b}}$, Sugayama, RL. ${ }^{\mathrm{c}}$, Specht, A. ${ }^{\mathrm{a}, \mathrm{d}}$ and Barros, NM. ${ }^{\mathrm{a} *}$ \\ ${ }^{a}$ Centro de Ciências Agrárias e Biológicas, Instituto de Biotecnologia, Universidade de Caxias do Sul - UCS, \\ Rua Francisco Getúlio Vargas, 1130, CEP 95070-560, Caxias do Sul, RS, Brazil

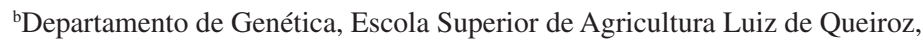 \\ Universidade de São Paulo - USP, Piracicaba, SP, Brazil \\ ${ }^{\mathrm{c}}$ Agropec Pesquisa, Extensão e Consultoria, Belo Horizonte, MG, Brazil \\ ${ }^{\mathrm{d} C e n t r o ~ d e ~ C i e ̂ n c i a s ~ E x a t a s, ~ d a ~ N a t u r e z a ~ e ~ d e ~ T e c n o l o g i a, ~ C a m p u s ~ U n i v e r s i t a ́ r i o ~ d a ~ R e g i a ̃ o ~ d o s ~ V i n h e d o s, ~}$ \\ Universidade de Caxias do Sul - UCS, Bento Gonçalves, RS, Brazil \\ *e-mail: nmbarros@ucs.br
}

Received May 5, 2009 - Accepted January 5, 2010 - Distributed November 30, 2010

(With 1 figure)

\begin{abstract}
Several insects are harmful to apples grown in Brazil, especially the leafroller Bonagota salubricola (Lepidoptera, Tortricidae), usually controlled with chemical insecticides. The purpose of the present study was to investigate the use of Metarhizium anisopliae strains in the control of the apple leafroller, by assessing their virulence to B. salubricola larvae in bioassays with suspensions of $2 \times 10^{5}$ to $2 \times 10^{9}$ conidia/mL as well as their relationship with protease expression. The most effective strain underwent a compatibility test with chemical insecticides. The M. anisopliae E6 strain showed a good performance, with up to $88 \%$ mortality and $\mathrm{LT}_{50}$ of 1.66 days. The virulence was positively correlated with a higher enzymatic activity. The E6 strain was compatible with tebufenozide, evidencing its potential to control B. salubricola.
\end{abstract}

Keywords: entomopathogenic fungi, apple, biological control, leafroller.

\section{Potencialidade de Metarhizium anisopliae (Metsch.) Sorokin (Ascomycetes, Hypocreales) no controle de Bonagota salubricola (Meyrick) (Lepidoptera, Tortricidae) e sua compatibilidade com inseticidas químicos}

\section{Resumo}

Diversos insetos são nocivos à macieira no Brasil, destacando-se a lagarta-enroladeira Bonagota salubricola (Lepidoptera: Tortricidae), controlada com inseticidas químicos. Este trabalho objetivou avaliar linhagens de Metarhizium anisopliae passíveis de serem utilizadas no controle desta praga, determinando-se a virulência sobre larvas de $B$. salubricola em bioensaios com suspensões de $2 \times 10^{5}$ a $2 \times 10^{9}$ conídios $/ \mathrm{mL}$ considerando-se mortalidade larval e pupal, bem como a sua relação com a expressão de proteases. A linhagem mais efetiva foi submetida a teste de compatibilidade com inseticidas químicos. A linhagem E6 de M. anisopliae destacou-se por proporcionar mortalidade de $88 \% \operatorname{com~TL}_{50}$ de 1,66 dias; tal virulência relacionou-se positivamente com maior produção enzimática. Esta linhagem foi compatível com tebufenozide, evidenciado seu potencial no controle de B. salubricola.

Palavras-chave: fungos entomopatogênicos, maçã, controle biológico, lagarta enroladeira da macieira.

\section{Introduction}

The Bonagota salubricola (Meyrick, 1931) (Lepidoptera: Tortricidae) leafroller, also known by a synonym, Bonagota cranaodes (Meyrick, 1937) (Brown and Razowski, 2003), is a primary pest in commercial apple orchards in South America.
The larvae feed mainly on the peel and pulp of the fruits, thus making them improper for commercialisation (Kovaleski et al., 1998).

The first leafroller attacks were identified in Brazil during the 1990s, and broad-spectrum chemical insecticides were used 
to control this pest. Up to eight insecticide applications were carried out by harvest and yet losses in the field still stayed around 3-5\% (Kovaleski et al., 1998), very much like in the control of Cydia pomonella (Linnaeus, 1758) (Lepidoptera: Tortricidae), which also damages apple orchards in other parts of the world (Lacey and Unruh, 2005).

Thereafter, pest-monitoring tools were developed, resulting in better management and fewer insecticide applications. Other products less toxic to the environment and to natural enemies such as growth regulators and modern molecules more efficient even at very low dosages were also developed. Both procedures - monitoring and use of less-toxic products - led to the reduction of pest population, which currently plays a less important economic role (Sugayama, R.L., personal observation).

The global market is currently inclined towards ecological products, leading fruit growers to adopt strategies as the Integrated Apple Production (IAP) (MAPA, 2006), reducing the use of agrochemicals or resorting to other alternatives (Way and Emden, 2000; Lacey and Unruh, 2005).

Thus, the use of natural agents such as entomopathogenic fungi can cut the use of chemical insecticides down to a minimum (Azevedo, 1998). These microorganisms produce epizootics in susceptible insects, with minimal effect on non-target species (Alves, 1998). Entomopathogenic fungi of the Beauveria, Metarhizium and Paecilomyces genera were already seen parasitising tortricidae (Humber and Hansen, 2005), indicating that it might be used for controlling B. salubricola (Robbs and Bittencourt, 1998). As to the potential of entomopathogenic fungi in pest control, several studies correlate enzymatic activity especially that of proteases with virulence, since they are directly involved in fungi ability in penetrating the host (Gupta et al., 1994; St. Leger et al., 1986; Tiago and Furlaneto, 2003).

Chemical insecticides and biological control by entomopathogenic fungi may be used alternatingly or simultaneously, if compatibility or - more rarely - synergism between them is identified (Alves, 1998; Silva et al., 2005). Thus, it is imperative to determine the compatibility between chemical insecticides and biological insecticides such as entomopathogenic fungi.

The purpose of the present study was to evaluate the potential of Metarhizium anisopliae (Metsch.) Sorokin in controlling $B$. salubricola as well as the compatibility of the more promising strain with chemical insecticides.

\section{Materials and Methods}

\subsection{Metarhizium anisopliae strains and target insect}

The study used strains E6, AL and CG46 of M. anisopliae. Strains E6 and AL were isolated from Deois flavopicta (Hemiptera: Cercopidae) from the Brazilian states of Espirito Santo and Alagoas, respectively (Rosato et al., 1981; Kava-Cordeiro et al., 1995). The CG46 (E9) strain, kindly provided by EMBRAPA, the Brazilian Agriculture and Cattle Research Institute, monosporic-culture, was isolated from Deois incompleta in the Brazilian state of
Espirito Santo (EMBRAPA, 1996). Strains were kept in stock in medium with potato dextrose agar (PDA) and grown in dishes with PDA at $25^{\circ} \mathrm{C}$ for 10-12 days for pathogenicity and virulence tests. $B$. salubricola insects were obtained from the breeding facilities of the Pest Control Laboratory of the Institute of Biotechnology of the University of Caxias do Sul, Brazil, where insects are bred in an air-conditioned room at $25 \pm 1{ }^{\circ} \mathrm{C}, 60 \pm 10 \%$ RH and 14 hours photophase, using the methodology and artificial diet as described in Parra et al. (1995).

\subsection{Virulence}

Virulence tests used conidia from the 10-12-day old culture of the first subculture in PDA against second-instar caterpillars, except for the most virulent strain, whose tests were complemented with first and fourth-instar caterpillars. Each strain was assessed in the concentrations of $2 \times 10^{5}, 2 \times 10^{6}, 2 \times 10^{7}, 2 \times 10^{8}$, and $2 \times 10^{9}$ conidia/ $\mathrm{mL}$, by wetting filter paper discs previously arranged in 9 -cm $\varnothing$ Petri dishes with $2 \mathrm{~mL}$ of suspension. Conidia viability was around $100 \%$. Caterpillars were kept in contact with the fungi for $24 \mathrm{~h}$ and were then put on artificial diet (Alves, 1998), and maintained at $25 \pm 1{ }^{\circ} \mathrm{C}$ and $60 \pm 10 \% \mathrm{RH}$, with daily assessments. The control group underwent the same procedures, however without addition of microorganisms. Treatments consisted of five repetitions with 10 caterpillars each, with daily mortality assessments until the pupal stage.

\subsection{Proteolytic activity}

Strains were revitalised by subculture in PDA to obtain conidia. For each strain, a suspension of $5.6 \times 10^{6}$ conidia $/ \mathrm{mL}$ was inoculated in $25 \mathrm{~mL}$ MM medium (Pontecorvo et al., 1953), without addition of nitrogen source and MM + CAS (MM plus $1 \% \mathrm{p} / \mathrm{v}$ casein solution). Glucose and $\mathrm{NaNO}_{3}$ were removed from the liquid media.

Each strain was inoculated in triplicate, incubated at $28^{\circ} \mathrm{C}$ under agitation (180 rpm), and proteolytic activity of two samples of each replicate was assessed. In all, six repetitions were made for each period of time $(0,24,48$, and 72 hours).

The samples were centrifuged at $2240 \mathrm{~g}$ for 10 minutes. The supernatant was kept at $-20{ }^{\circ} \mathrm{C}$ and used as secreted fraction in the enzymatic assays. Subtilisin-like (Pr1) was determined using the specific synthetic substrate Scu-Ala-Ala-Pro-Phe- -nitroanilide (Gupta et al., 1992). After induction at $28{ }^{\circ} \mathrm{C}$ for 30 minutes, the reaction was stopped with $250 \mu \mathrm{L}$ acetic acid (30\%), the rate of substrate hydrolysis with release of $p$-nitroanilide was quantified by spectrophotometer $(410 \mathrm{~nm})$, and the results were expressed in nmols of $p$-nitroanilide in 30 minutes.

\subsection{Compatibility between fungus and agrochemicals}

The most virulent fungal strain (E6) was tested for compatibility with following chemical insecticides used in apple orchards: chlorpyrifos-ethyl (Lorsban 480BR $72 \mathrm{~g}$ a.i./100 L), methidathion (Supracide 400CE - $60 \mathrm{~g}$ a.i./100 L), tebufenozide (Mimic 240SC - 21.6 g a.i./100 L), and fenitrotion (Sumithion $500 \mathrm{CE}-75 \mathrm{~g}$ a.i./100 L). 
Compatibility was assessed in vitro by evaluating vegetative growth and sporulation of entomopathogens in the presence or absence of each insecticide. Products were added in culture medium (PDA) at $45 \pm 5{ }^{\circ} \mathrm{C}$ and poured onto Petri dishes in 25-mL aliquots. Entomopathogen inoculation was performed with a platinum loop at three equidistant spots. Twelve inoculations per insecticide were performed, with Petri dishes being kept at $26 \pm 1{ }^{\circ} \mathrm{C}$, $70 \pm 10 \% \mathrm{RH}$, and 12-h photophase for ten days. The same procedure was used for the controls, however without addition of agrochemicals.

Vegetative growth was assessed by determining the average diameter of the colonies in three directions. The number of spores was estimated by removing a $15-\mathrm{mm} \varnothing$ disk at each inoculation spot, and then transferring it to a flask with Tween 80 aqueous solution $(0.1 \% \mathrm{v} / \mathrm{v})$, agitating it for 5 minutes, and then estimating spore concentration in a Neubauer chamber (Oliveira et al., 2002).

\subsection{Data analysis}

The mean rates of accumulated mortality were compared by analysis of variance (ANOVA) and means were grouped by Tukey's test at a probability of $95 \%$. Virulence was assessed by the Probit model (Finney, 1971) by determining $\mathrm{LC}_{50}$ and $\mathrm{LT}_{50}$, while the correlation between concentrations and mortality was assessed by Pearson's test.

The data obtained in the compatibility study between fungi and agrochemicals were compared with the compatibility factor proposed by Alves et al. (1998), which groups products in selectivity/compatibility classes by using the following equation:

\section{$\mathrm{T}=20[\mathrm{VG}]+80[\mathrm{SPO}] / 100$}

where: $\mathrm{T}=$ the corrected value for product classification; $\mathrm{VG}=$ percent of vegetative growth in relation to control, and SPO = percent of sporulation (conidiogenesis) in relation to control.

The following limits were established for "T": 0-30\% = highly toxic; $31-45 \%=$ toxic; $46-60 \%=$ mildly toxic; $>$ $60 \%=$ compatible.

\section{Results}

\subsection{Virulence}

At the highest fungal concentration, virulence to $B$. salubricola ranged between 38 and $88 \%$ on the tenth day (Table 1). Strain AL at highest concentration induced a $54 \%$ mortality rate (Table 1 ), with an average lethal concentration $\left(\mathrm{LC}_{50}\right)$ of $2.78 \times 10^{8}\left(2.10 \times 10^{8}\right.$ to $\left.3.27 \times 10^{8}\right)$ conidia/mL, $\left(\chi^{2} 1.787\right)$ average lethal time $\left(\mathrm{LT}_{50}\right)$ of 8.42 (6.88 to 10.35$)$ days $\left(\chi^{2} 4.725\right)$, and a positive correlation between concentration and mortality $(\mathrm{PC}=0.794)$, which increased until the tenth day (Figure 1).

Strain CG46 at the highest concentration induced a 38\% mortality rate (Table 1 ) with a merely numerical correlation between concentration and mortality $(\mathrm{PC}=0.634)$, which also increased until the tenth day.
Strain E6 at the highest concentration induced an $88 \%$ mortality rate (Table 1 ), with $\mathrm{LC}_{50}$ of $2.68 \times 10^{7}$ $\left(2.52 \times 10^{7}\right.$ to $\left.2.74 \times 10^{7}\right)$ conidia $/ \mathrm{mL},\left(\chi^{2} 0.336\right)$ conidia $/ \mathrm{mL}$ and $\mathrm{LT}_{50}$ of 1.66 days (1.50 to 1.68$)$ days $\left(\chi^{2} 3.718\right)$. A positive correlation between mortality and concentration $(\mathrm{PC}=0.774)$ was observed, and mortality stabilised on the fifth day of the bioassay (Figure 1).

Strain E6 at the highest concentration induced an $82 \%$ mortality rate in first-instar larvae (Table 2), with a positive correlation between mortality and concentration $(\mathrm{PC}=0.889)$. As for fourth-instar larvae, mortality rate was significant only at highest concentration (48\%), with a high positive correlation being observed between concentration and mortality $(\mathrm{PC}=0.997)$.

\subsection{Proteolytic activity}

All strains (Table 3) cultured in MM + CAS showed increasing rates of enzymatic activity in relation to culture time. Strains AL and CG46 expressed significant enzymatic activity at 72 hours, while strain E6 presented a significant increase at 48 hours and the highest rate observed (U 14.82) at 72 hours.

\subsection{Compatibility between fungus and insecticides}

According to $t$-test, strain E6 was compatible with tebufenozide and did not significantly differ from the control group with regard to vegetative growth and sporulation, having been considered compatible (Table 4).

Table 1. Accumulated mortality (\%) of second-instar caterpillars $(\mathrm{n}=50)$ of Bonagota salubricola inassays with different strainsand concentrations of Metarhizium anisopliae.

\begin{tabular}{|c|c|c|c|c|}
\hline \multirow{2}{*}{ Strains } & \multirow{2}{*}{ Concentration } & \multicolumn{3}{|c|}{ Larval mortality } \\
\hline & & $1^{\text {st }}$ day & $5^{\text {th }}$ day & $10^{\text {th }}$ day \\
\hline \multirow[t]{6}{*}{$\mathrm{AL}$} & Control & $0^{\mathrm{a}}$ & $4^{a}$ & $6^{\mathrm{a}}$ \\
\hline & $2 \times 10^{5}$ & $0^{\mathrm{a}}$ & $6^{\mathrm{a}}$ & $10^{\mathrm{a}}$ \\
\hline & $2 \times 10^{6}$ & $0^{\mathrm{a}}$ & $10^{\mathrm{ab}}$ & $18^{\mathrm{ab}}$ \\
\hline & $2 \times 10^{7}$ & $4^{a}$ & $12^{\mathrm{ab}}$ & $28^{\mathrm{abc}}$ \\
\hline & $2 \times 10^{8}$ & $4^{\mathrm{a}}$ & $26^{\mathrm{ab}}$ & $40^{\mathrm{bc}}$ \\
\hline & $2 \times 10^{9}$ & $2^{\mathrm{a}}$ & $36^{\mathrm{b}}$ & $54^{\mathrm{c}}$ \\
\hline \multirow[t]{6}{*}{$\mathrm{CG}$} & Control & $0^{\mathrm{a}}$ & $6^{\mathrm{a}}$ & $6^{\mathrm{a}}$ \\
\hline & $2 \times 10^{5}$ & $0^{\mathrm{a}}$ & $8^{\mathrm{a}}$ & $10^{\mathrm{ab}}$ \\
\hline & $2 \times 10^{6}$ & $0^{\mathrm{a}}$ & $10^{\mathrm{a}}$ & $12^{\mathrm{abc}}$ \\
\hline & $2 \times 10^{7}$ & $2^{\mathrm{a}}$ & $22^{\mathrm{a}}$ & $30^{\mathrm{abc}}$ \\
\hline & $2 \times 10^{8}$ & $2^{\mathrm{a}}$ & $16^{\mathrm{a}}$ & $34^{\mathrm{bc}}$ \\
\hline & $2 \times 10^{9}$ & $0^{\mathrm{a}}$ & $22^{\mathrm{a}}$ & $38^{c}$ \\
\hline \multirow[t]{6}{*}{ E6 } & Control & $0^{\mathrm{a}}$ & $2^{\mathrm{a}}$ & $2^{a}$ \\
\hline & $2 \times 10^{5}$ & $0^{\mathrm{a}}$ & $0^{\mathrm{a}}$ & $4^{\mathrm{a}}$ \\
\hline & $2 \times 10^{6}$ & $0^{\mathrm{a}}$ & $4^{\mathrm{a}}$ & $4^{\mathrm{a}}$ \\
\hline & $2 \times 10^{7}$ & $0^{\mathrm{a}}$ & $38^{\mathrm{b}}$ & $40^{\mathrm{b}}$ \\
\hline & $2 \times 10^{8}$ & $0^{\mathrm{a}}$ & $62^{\mathrm{b}}$ & $66^{\mathrm{bc}}$ \\
\hline & $2 \times 10^{9}$ & $0^{\mathrm{a}}$ & $88^{c}$ & $88^{c}$ \\
\hline
\end{tabular}

Averages followed by different letters indicate significance $(\mathrm{p}<0.05)$ of mortality rate by concentrations of each strain (columns) and times (lines). 


\section{Discussion}

In this study, all strains showed pathogenicity to $B$. salubricola, especially strain E6 (Table 1). This strain induced the highest mortality rates, lowest $\mathrm{LT}_{50}$ (1.66 days) with high enzymatic activity, indicating virulence (Silva, 2003), since enzymatic activity might be associated with a higher ability of penetrating the insect's cuticle (Gupta et al., 1994; St.Leger et al., 1986; Tiago and Furlaneto, 2003). High Pr1, E6 levels are related with the shortest mortality time, as observed by Gupta et al. (1994). Enzymatic

Table 2. Accumulated mortality rate of first and fourthinstar Bonagota salubricola caterpillars $(n=50)$ in assays with strain E6 (Metarhizium anisopliae) at different concentrations.

\begin{tabular}{lcccc}
\hline \multirow{2}{*}{ Instar } & \multirow{2}{*}{ Concentration } & \multicolumn{3}{c}{ Confirmed mortality } \\
\cline { 3 - 5 } & & $\mathbf{1}^{\text {st }} \mathbf{d a y}$ & $\mathbf{5}^{\text {th }}$ day & $\mathbf{1 0}^{\text {th }} \mathbf{d a y}$ \\
\hline First & Control & $0^{\mathrm{a}}$ & $6^{\mathrm{a}}$ & $16^{\mathrm{a}}$ \\
& $2 \times 10^{5}$ & $0^{\mathrm{a}}$ & $16^{\mathrm{a}}$ & $20^{\mathrm{a}}$ \\
& $2 \times 10^{7}$ & $4^{\mathrm{a}}$ & $41^{\mathrm{b}}$ & $46^{\mathrm{b}}$ \\
& $2 \times 10^{9}$ & $6^{\mathrm{a}}$ & $74^{\mathrm{d}}$ & $82^{\mathrm{a}}$ \\
Fourth & Control & $0^{\mathrm{a}}$ & $0^{\mathrm{a}}$ & $0^{\mathrm{a}}$ \\
& $2 \times 10^{5}$ & $0^{\mathrm{a}}$ & $0^{\mathrm{a}}$ & $0^{\mathrm{a}}$ \\
& $2 \times 10^{7}$ & $0^{\mathrm{a}}$ & $4^{\mathrm{a}}$ & $4^{\mathrm{a}}$ \\
& $2 \times 10^{9}$ & $0^{\mathrm{a}}$ & $48^{\mathrm{c}}$ & $48^{\mathrm{c}}$ \\
\hline
\end{tabular}

Averages followed by different letters indicate significance $(\mathrm{p}<0.05)$ of mortality rate of each strain by concentration (column) and time (line). activity either for subtilisin-like Pr1 and trypsin-like Pr2 was higher in MM + CAS than in MM, being related to the level of carbon and nitrogen sources, as well as the presence of inducer proteins in the medium (Morais et al., 2003; Campos et al., 2005).

The higher mortality of B. salubricola in the first and second instars in relation to the fourth instar is due in part to the cuticle's hydrophobicity, which in the first instars favours spore adherence and consequently increases host susceptibility to fungal propagules (Boucias et al., 1988).

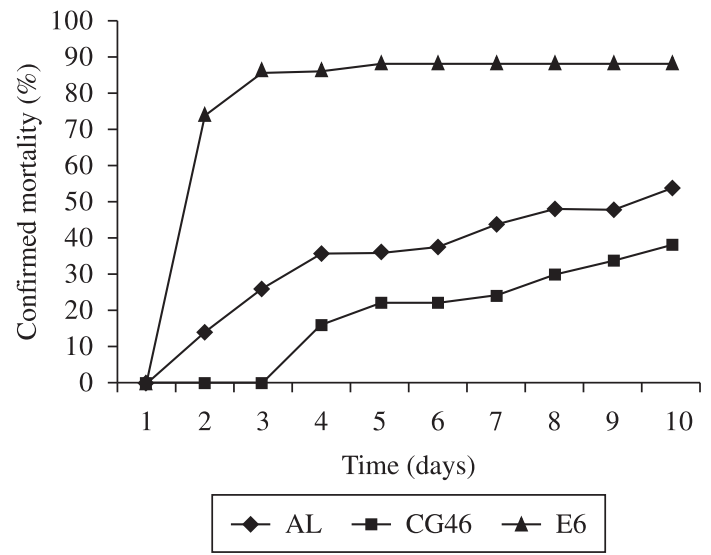

Figure 1. Accumulated mortality (\%) of second-instar Bonagota salubricola caterpillars $(\mathrm{n}=50)$ in assays with strains of Metarhizium anisopliae $(\bullet-\mathrm{AL} \rightarrow \mathrm{CG} 46 \rightarrow \mathrm{E} 6)$ in a concentration of $2 \times 10^{9}$ conidia $/ \mathrm{mL}$.

Table 3. Subtilisin-like (Pr1) proteolytic activity (U) of Metarhizium anisopliae in MM and MM + CAS.

\begin{tabular}{clcccc}
\hline \multirow{2}{*}{ Strain } & \multirow{2}{*}{ Culture medium } & \multicolumn{4}{c}{ Time } \\
\cline { 3 - 6 } & & $\mathbf{0 ~ h}$ & $\mathbf{2 4} \mathbf{h}$ & $\mathbf{4 8 ~ h}$ & $\mathbf{7 2} \mathbf{h}$ \\
\hline \multirow{2}{*}{$\mathrm{AL}$} & $\mathrm{MM}$ & $0.003 \pm 0.005^{\mathrm{a}}$ & $0.060 \pm 0.050^{\mathrm{a}}$ & $0.150 \pm 0.145^{\mathrm{a}}$ & $0.076 \pm 0.070^{\mathrm{a}}$ \\
& $\mathrm{MM}+$ Cas & $0.066 \pm 0.058^{\mathrm{a}}$ & $0.166 \pm 0.144^{\mathrm{a}}$ & $0.263 \pm 0.196^{\mathrm{a}}$ & $8.870 \pm 2.255^{\mathrm{b}}$ \\
\multirow{2}{*}{$\mathrm{CG} 46$} & $\mathrm{MM}$ & $0.014 \pm 0.025^{\mathrm{a}}$ & $0.037 \pm 0.034^{\mathrm{a}}$ & $0.077 \pm 0.080^{\mathrm{a}}$ & $0.009 \pm 0.009^{\mathrm{a}}$ \\
& $\mathrm{MM}+\mathrm{Cas}$ & $0.104 \pm 0.125^{\mathrm{a}}$ & $0.268 \pm 0.252^{\mathrm{a}}$ & $0.277 \pm 0.145^{\mathrm{a}}$ & $9.920 \pm 0.585^{\mathrm{b}}$ \\
& $\mathrm{E} 6$ & $0.000 \pm 0.000^{\mathrm{a}}$ & $0.054 \pm 0.078^{\mathrm{a}}$ & $0.062 \pm 0.092^{\mathrm{a}}$ & $0.062 \pm 0.092^{\mathrm{a}}$ \\
& $\mathrm{MM}$ & $0.112 \pm 0.097^{\mathrm{a}}$ & $1.189 \pm 0.866^{\mathrm{a}}$ & $9.286 \pm 2.926^{\mathrm{b}}$ & $14.82 \pm 1.925^{\mathrm{c}}$ \\
\hline
\end{tabular}

$\mathrm{U}\left(\mathrm{nmol}\right.$ of $\mathrm{p}$-nitroanilide. $\left.\mathrm{mL}^{-1} \cdot \mathrm{min}^{-1}\right)$. *Averages followed by different letters indicate significance $(\mathrm{p}<0.05)$ between $\mathrm{U}$ values, for each strain in relation to incubation time (line) and culture medium (column).

Table 4. In vitro compatibility of insecticides and M. anisopliae (E6 strain) according to vegetative growth (mm), spore number, compatibility factor " $\mathrm{T}$ " and respective classification.

\begin{tabular}{lcccc}
\hline Treatment & Vegetative growth & Qty. of spores & T \% & Classification \\
\hline Control & $35.08 \pm 3,19^{\mathrm{a}}$ & $4.07 \times 10^{6}$ & - & - \\
Tebufenozide & $34.88 \pm 1.59^{\mathrm{a}}$ & $4.49 \times 10^{6}$ & 108.22 & Compatible \\
Methidathion & $5.03 \pm 0.2^{\mathrm{b}}$ & $6.20 \times 10^{4}$ & 4.08 & Highly toxic \\
Fenitrothion & $7.48 \pm 0.66^{\mathrm{b}}$ & $4.20 \times 10^{4}$ & 5.09 & Highly toxic \\
Chlorpyrifos & $5.33 \pm 0.78^{\mathrm{b}}$ & $1.50 \times 10^{4}$ & 3.41 & Highly toxic \\
\hline
\end{tabular}

Averages followed by the same letter do not statistically differ $(\mathrm{p}<0.05)$. *Highly toxic: between 0 and $30 \%$; compatible: above $61 \%$ (Alves et al., 1998). 
Other defense mechanisms include those performed by hemocytes, free cells circulating in the hemolymph, the number and types differ between species, age and stage of development (Gupta, 1985).

Results have shown that according to development stage of B. salubricola biological control with $M$. anisopliae might be an interesting alternative for $B$. salubricola control, since the mortality rate induced by strain E6 $(82 \%)$ in first-instar larvae (Table 3) almost reached the $100 \%$ mortality rate of chemical insecticides chlorpyrifosethyl, methidathion, phosmet, trichlorfon, tebufenozide, fenitrotion, and carbaryl (Botton et al., 2000). With the fourth instar, mortality reached $48 \%$ (Table 3 ), a higher rate than that observed by Botton et al. (2000) with phosmet (27.7\%), fenitrotion (22.2\%) and methidathion (28.9\%), and a lower mortality rate than with trichlorfon $(80.6 \%)$, chlorpyrifos $(88.8 \%)$, tebufenozide $(83.3 \%)$, and carbaryl $(55.6 \%)$. The selection of entomopathogenic fungi might ensure control of the apple leafroller in a more economical and safer way to humans and to the environment, as already shown with other pests and crops (Alves and Lopes, 2008), and as advocated by integrated management programmes (Way and Emden, 2000; Kovaleski and Ribeiro, 2003). In this respect, E6 emerges as the most virulent strain and the one with compatibility with tebufenozide. This compatibility allows their joint use in controlling the target pest more efficiently.

The use of an entomopathogen in the control of $B$. salubricola will also allow preserving known natural enemies, predators and parasitoids, thus maintaining the natural balance and decreasing those impacts routinely observed in orchards using the traditional management system on humans and the environment.

Acknowledgements - Research supported by CAPES. We express our thanks to the referees for the extensive review and contributions made to improve our manuscript.

\section{References}

ALVES, SB. and LOPES, RB. (Eds.)., 2008. Controle Microbiano de Pragas na América Latina - Avanços e Desafios. Piracicaba: FEALQ. 414 p.

ALVES, SB., 1998. Controle Microbiano de Insetos. Piracicaba: FEALQ. 1163 p.

ALVES, SB., MOINO Jr., A. and ALMEIDA, JEM., 1998. Produtos fitossanitários e entomopatógenos. In ALVES, SB. (Ed.). Controle Microbiano de Insetos. Piracicaba: FEALQ. p. 217-238.

AZEVEDO, JL., 1998. Controle Microbiano de insetos-pragas e seu melhoramento genético. In MELO, IS. and AZEVEDO, JL. (Eds.). Controle Biológico. Jaguariúna: Embrapa. v. 1, p. 69-96.

BOTTON, M., NAKANO, O. and KOVALESKI, A., 2000. Controle químico da Lagarta-Enroladeira (Bonagota salubricola Meyrick) na cultura da macieira. Pesquisa Agropecuária Brasileira, vol. 35, no. 11 , p. $2139-2144$.

BOUCIAS, DG., PENDLAND, JC. and LATGE, JP., 1988. Nonspecific factors in attachment of entomopathogenic deuteromycetes to host cuticle. Applied and Environmental Microbiology, vol. 54, no. 7, p. 1795-1805.

BROWN, JW. and RAZOWSKI, J., 2003. Description of Ptychocroca, a new genus from Chile and Argentina, with comments on the Bonagota Razowski group of genera (Lepidoptera: Tortricidae: Euliini). Zootaxa, vol. 303, no. 1, p. 1-31.

CAMPOS, RA., ARRUDA, W., BOLDO, JT., SILVA, M., BARROS, NM., AZEVEDO, JL., SCRHANK, A. and VAINSTEIN, MH., 2005. Boophilus microplus Infection by fungi: a speculative review. Current Microbiology, vol. 50, no. 5, p. 257-261.

Empresa Brasileira de Pesquisa Agropecuária - EMBRAPA, 1996. Coleção de Fungos entomopatogênicos do CENARGEN. Brasília, DF: CENARGEN. 76 p.

FINNEY, DJ., 1971. Probit analysis. 3 ed. London: Cambridge University Press. 25 p.

GUPTA, AP., 1985. Cellular elements in hemolynph. In KERKUT, GA. and GILBERT, LI. (Eds.). Comprehensive insect physiology, biochemistry and phamacology. Oxford: Pergamon Press. v. 3, p. 401-451.

GUPTA, SC., LEATHERS, TD., EL-SAYED, GN. and IGNOFFO, CM., 1994. Relationships among enzyme activities and virulence parameters in Beauveria bassiana infections of Galleria mellonella and Trichoplusia ni. Journal of Invertebrate Pathology, vol. 64, no. 1, p. 13-17.

-, 1992. Insect cuticle-degrading enzymes from the entomopathogenous fungus Beauveria bassiana. Experimental Mycology, vol. 16, p. 132-137.

HUMBER, RA. and HANSEN, KS., 2005. Catalog of Isolates. Tower Road, Ithaca, USA: USDA-ARS Plant Protection Research Unit, US Plant, Soil \& Nutrition Laboratory.

KAVA-CORDEIRO, V., LUNA-ALVES-LIMA, EA. and AZEVEDO, JL., 1995. Survival and mutant production induced by mutagenic agents in Metarhizium anisopliae. Scientia Agricola, vol. 52, p. $548-554$

KOVALESKI, A. and RIBEIRO, LG., 2003. Manejo de pragas na produção integrada de maçã. In Empresa Brasileira de Pesquisa Agropecuária - EMBRAPA. Produção Integrada de Frutos: $\mathrm{O}$ caso da maçã no Brasil. Bento Gonçalves: Embrapa Uva e Vinho. p. 61-68.

KOVALESKI, A., BOTTON, M., EIRAS, AE. and VILELA, E., 1998. Lagarta-enroladeira da macieira Bonagota salubricola (Meyrick, 1937) (Lepidoptera: Tortricidae): bioecologia, monitoramento e controle. Bento Gonçalves: Embrapa Uva e Vinho. 16 p. Circular Técnica 24.

LACEY, LA. and UNRUH, TR., 2005. Biological Control Of Codling Moth (Cydia pomonella, Lepidoptera: Tortricidae) And Its Role In Integrated Pest Management, With Emphasis On Entomopathogens. Vedalia, vol. 12, no. 1, p. 33-60.

Ministério da Pecuária e Abastecimento - MAPA, 2006. Instrução Normativa $\mathrm{N}^{\circ} 01$, Normas técnicas específicas para a produção integrada de maçã - Ntepi-Maçã. Diário Oficial da União, Brasília, DF, 21 set. 2006.

MORAIS, CK., SCHRANK, A. and VAINSTEIN, MH., 2003. Regulation of extracellular chitinases and proteases in the entomopathogen and acaricide Metarhizium anisopliae. Current Microbiology, vol. 46. p. 205-210. 
OLIVEIRA, RC., NEVES, PMOJ., GUZZO, EC. and ALVES, VS., 2002. Compatibilidade de fungos entomopatogênicos com agroquímicos. Semina: Ciências Agrárias, vol. 23, p. 211-216.

PARRA, JRP., EIRAS, AE., HADDAD, ML., VIELA, EF. and KOVALESKI, A., 1995. Técnica de Criação de Phtheocroa salubricola Meyrick (Lepidoptera:Tortricidae) em dieta artificial. Revista Brasileira de Biologia = Brazilian Journal of Biology, vol. 55, p. 537-543.

PONTECORVO, G., ROPER, JA., HEMONS, LM., MACDONALD, KD. and BUFTON, AWJ., 1953. The genetics of Aspergillus nidulans. Advances in Genetics, vol. 5, p. 141-238.

ROBBS, CF. and BITTENCOURT, AM., 1998. Controle Biológico de Insetos - O controle Biológico de Insetos Nocivos à Agricultura com o Emprego de Fungos Imperfeitos ou Hifomicetos. Biotecnologia Ciência \& Desenvolvimento, vol. 6, no. 1, p. 10-12.

ROSATO, YB., MESSIAS, CL. and AZEVEDO, JL. 1981. Productions of extracellular enzymes by isolates of Metarhizium anisopliae. Journal of Invertebrate Pathology, vol. 38, p. 1-3.
SILVA, RZ., NEVES, PMOJ. and SANTORO, PH., 2005. Técnicas e parâmetros utilizados nos estudos de compatibilidade entre fungos entomopatogênicos e produtos fitossanitários. Ciências Agrárias, vol. 26, no. 3, p. 305-312.

SILVA, VCA., 2003. Suscetibilidade de Plutella xylostella (L.) (Lepidoptera: Plutellidae) aos fungos Beauveria bassiana e Metarhizium anisopliae (Metsch.) Sorok. Neotropical Entomology., vol. 32 , no. 4, p. 653-658.

St. LEGER, RJ., CHARNLEY, AK. and COOPER, RM., 1986. Cuticle-degrading enzymes of entomopatogenic fungi: Mechanisms of interaction between pathogen enzymes and insect cuticle. Journal of Invertebrate Pathology, vol. 47, p. 295-302.

TIAGO, PV. and FURLANETO, MC., 2003. O papel de proteases degradadoras de cutícula produzidas por fungos entomopatogênicos. Revista do Programa de Ciências Agro-Ambientais, vol. 2, no. 1, p. 40-51.

WAY, MJ. and EMDEN, HF. van, 2000. Integrated pest management in practice: pathways towards successful application. Review. Crop Protection, vol. 19, p. 81-103. 